\title{
Sett av dato 17. - 19. april 2015!
}

I 2015 arrangeres NUFD sitt årlige symposium på Røros i perioden 15. - 17. april. Møtested er Røros Hotell.

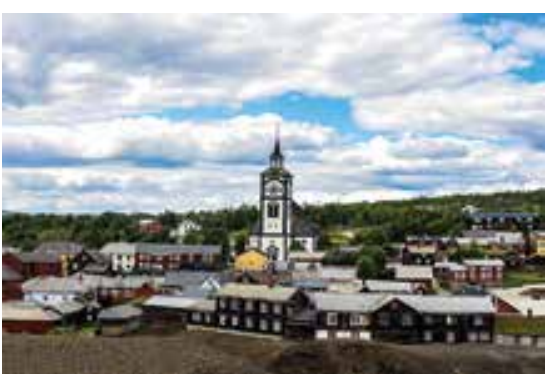

Fig. 1 Røros

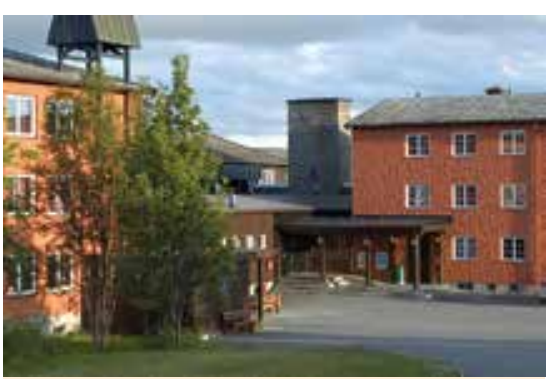

Fig. 2 Røros Hotell

Styret er i gang med å sette sammen et variert program fra fagområdene radiologi, gastroenterologi, muskelskjelett, akuttmedisin, gynekologi og obstetrikk.

Onsdagen fra kl. 9 til kl. 16 er avsatt til "Basalkurs i ultralydfysikk og apparatelære“. Kurset omfatter ultralydfysikk og „knottologi“, artefakter i ultralydbilde, Doppler, sikkerhet og etikk ved ultralyd og praktisk undervisning på stasjoner "Abdomen“, "Muskelskjelett", "Obstetrikk/ gynekologi“" og "Akuttmedisin, hjerte og Doppler“, der en går inn på ergonomi og hygiene samt normal anatomi. NFUD ønsker å lansere dette som et tverrfaglig grunnleggende ultralydkurs, som kan danne basis for videre læring av medisinsk ultralyd i flere spesialiteter. Onsdagen gir derfor grunnlag for eget kursbevis. Vi håper på mange nye og noen erfarne ultra- lydbrukere på dette kurset. Onsdag ettermiddag tilbys en egen sesjon for jordmødre, som har spesialisert seg på prenatal ultralyd.

Har du et spennende prosjekt eller kasuistikk innenfor ultralyd, er du velkommen til å presentere dette i form av et fritt foredrag. Beste frie foredraget honoreres med 10000 NOK.

Styret vil samtidig minne om forskerstipendiet på 10000 NOK, som utløses årlig av NFUD i forbindelse med symposiet. Vi oppfordrer derfor alle, som er i gang med eller planlegger prosjekter innen ultralyd, å søke.

1. mars 2015 er frist for både påmelding, innsending av abstrakt og søknad om forskerstipend.

Nærmere informasjon om programmet legges etter hvert ut på nettsiden http:// www.nfud.no/. 